\title{
Implikasi Yuridis Pemalsuan Tanda Tangan Pada Minuta Akta terhadap Jabatan Notaris (Studi Putusan Mahkamah Agung Nomor 1234 K/ Pid/2012)
}

\author{
Dhea Mardheana \\ Magister Kenotariatan, Universitas Islam Indonesia \\ Jl. Cik Di Tiro No. 1 Yogyakarta \\ dheam@gmail.com
}

\begin{abstract}
Problems in this study, first: how is the juridical implications forged the signatures on the minutes of the deed of the Notary on the Supreme Court judgment No. 1234 k PID / 2012? Second, how is the legal effect of the Minuta Deed falsified by a notary? This study is normative, normative legal research. The study concluded, first: implications for the post of notary can be categorized into four (4) aspects namely, i) the implications of the engagement deed, ii) Aspects of the administrative office; iii) Professional Aspects of the Membership; vi), the criminal aspect. Second, as a result of the Law of Minuta certificates were forged by a Notary which resulted in deed only has the strength of evidence as the deed under hand, if the parties could prove the authentic act proficiency level in the trial court and resulted in the deed can be canceled and the strength of evidence as the deed under hand will not apply continuing involvement.
\end{abstract}

Keywords: Notary, forgery of signatures, Suspect

\begin{abstract}
Abstrak
Permasalahan dalam penelitian ini, pertama: bagaimanakah implikasi yuridis pemalsuan tanda tangan pada minuta akta terhadap Jabatan Notaris atas putusan Mahkamah Agung Nomor 1234 k/PID/2012? Kedua, bagaimanakah akibat hukum terhadap Minuta Akta yang dipalsukan oleh notaris? Penelitian ini merupakan penelitian normatif, Penelitian hukum normatif. Hasil penelitian menyimpulkan, pertama: implikasi terhadap jabatan notaris dapat dikategorikan dalam empat (4) aspek yakni, i) implikasi perikatan akta, ii) Aspek terhadap jabatan Administrasi; iii), Aspek Profesi terhadap Keanggotaan; vi), aspek pidana. Kedua, akibat Hukum terhadap Minuta akta yang dipalsukan oleh Notaris yaitu mengakibatkan akta hanya mempunyai kekuatan pembuktian sebagai akta di bawah tangan, apabila para pihak dapat membuktikan ketidakbenaran akta otentik tesebut dalam persidangan di pengadilan dan mengakibatkan akta tersebut dapat dibatalkan serta kekuatan pembuktian sebagai akta di bawah tangan tidak akan berlaku lagi.
\end{abstract}

Kata-kata Kunci: Notaris, pemalsuan tanda tangan, tersangka 


\section{Pendahuluan}

Notaris sebagai Pejabat umum memeiliki peranan sentral dalam menegakkan hukum di indonesia, karena selain kuantitas notaris yang begitu besar, notaris dikenal masuk kelompok elit di indonesia. Masyarakat masih membutuhkan seorang penulis selama ada tulisan, terutama untuk melayani mereka yang tidak menguasai tulis menulis. Penulis yang dimaksud akan bertindak sebagai saksi bagi mereka yang memerlukanya. Tulisannya jelas dan dapat dipercaya dan menyatakan apa yang dilakukan oleh yang meminta bantuan itu. Fungsi kecakapan menulis inilah yang merupakan dasar dari apa yang dewasa ini dinamakan sebagai Notariat. ${ }^{1}$

Notaris merupakan profesi yang terhormat dan selalu berkaitan dengan moral dan etika ketika menjalankan tugas jabatannya. Saat menjalankan tugas jabatannya, Notaris/PPAT berpegang teguh dan menjunjung tinggi martabat profesinya sebagai jabatan yang terhormat. Karena lekatnya etika pada profesi notaris disebut sebagai profesi yang mulia (officium nobile). ${ }^{2}$

Pengertian notaris, terdapat pada Pasal 1 ayat 1 Undang-Undang Nomor 2 tahun 2014 tentang Jabatan Notaris yang menyatakan "Notaris adalah pejabat umum yang berwenang untuk membuat akta otentik dan memiliki kewenangan lainnya sebagaimana dimaksud dalam undang-undang ini atau berdasarkan undang-undang lainnya."3

Notaris sebagai manusia bebas dan menjadi elmemen penting dalam pembangunan bangsa kiranya harus lekat dengan sifat-sifat humanisme mengingat perananya yang signifikan dalam lalu lintas kemasyarakatan, notaris sebagai pejabat negara yang berwenang membuat akta sedikit banyak berpengaruh pada hak dan kewajiban para pihak yang menghadap kepadanya, adanya legalisasi dari notaris memang sangat diperlukan untuk membuktikan akan adanya suatu perbuatan serta hak dan kewajiban tertentu. ${ }^{4}$

Notaris juga berkewajiban menurut kode etik notaris yaitu Etika pelayanan terhadap klien, sebagai pejabat umum notaris dapat memberika pelayanan hukum kepada masyarakat yang memerlukan jasanya dengan sebaik-baiknya, menyelesaikan akta sampai tahap pendaftaran pada pengadilan negeri dan pengumuman dalam beita negara, apabila klien

\footnotetext{
1 Soertardjo Soemoatmodjo, Apakah Notaris Pejabat Pembuat akta Tanah Pejabat lelang, Liberty, Yogyakarta, 1986, hlm 3.

2 Abdul Ghofur Anshori, Lembaga Kenotariatan Indonesia,Perspektif Hukum dan Etika, UII Press, Yogyakarta, 2009 hlm. 6.

${ }^{3}$ Lihat Pasal 1 ayat 1 Undang-Undang Republik Indonesia Nomor 2 Tahun 2014 Tentang Jabatan Notaris.

${ }^{4}$ Abdul Ghofur Anshori, Op. Cit... Hlm 5.
} 
yang bersangkutan dengan tegas menyatakan akan menyerahkan pengurusannya kepada notaris yang bersangkutan dan kliennya akan memenuhi syarat yang diperlukan. ${ }^{5}$

Akta otentik pada hakikatnya memuat kebenaran formal sesuai dengan apa yang diberitahukan para pihak kepada Notaris. Namun, Notaris mempunyai kewajiban untuk memastikan bahwa apa yang termuat dalam Akta Notaris sungguh-sungguh telah dimengerti dan sesuai dengan kehendak para pihak, yaitu dengan cara membacakannya sehingga menjadi jelas isi Akta Notaris, serta memberikan akses terhadap informasi mengenai peraturan perundang-undangan yang terkait bagi para pihak penandatangan akta. Dengan demikian, para pihak dapat menentukan dengan bebas untuk menyetujui atau tidak menyetujui isi Akta Notaris yang akan ditandatanganinya. Tanda tangan pada suatu akta otentik tersebut berfungsi sebagai tanda persetujuan terhadap kewajiban-kewajiban yang melekat pada akta ${ }^{6}$.

Minuta akta bisa dikatakan nyawa seorang notaris, di dalam minuta itu berisi kehendak para penghadap atau para pihak dan dibagian akhir akta itu tertera tanda tangan para pihak dan Notarisnya. Sebelum akta itu di tanda tangani, Notaris wajib harus membacakan isi dari akta tersebut agar di mengerti oleh para penghadap. Sekalipun tidak dibacakan, para penghadap harus memberi paraf pada setiap akta tersebut.

Salinan Akta adalah Salinan kata demi kata dari seluruh akta dan pada bagian bawah akta tercantum Frasa “diberikan sebagai salinan yang sama bunyinya.” Diperuntukkan klien yang minta agar akta tersebut dibuat dihadapan notaris, Pembuatan salinan akta harus berpedoman terhadap minuta aktanya. Salinan akta ada setelah minuta akta dibuat oleh Notaris. Pengertian salinan akta diperjelas dalam Pasal 1 angka 9 UUJN yaitu salinan kata demi kata dari seluruh akta dan pada bagian bawah salinan akta tercantum frasa "diberikan sebagai salinan yang sama bunyinya". Dalam salinan akta ada pernyataan Notaris dimulai dari awal akta dan akhir akta. Awal akta menerangkan bahwa para pihak telah menghadap kepada Notaris dan di akhir akta ada keterangan mengenai minuta akta tersebut telah ditandatandangani dengan sempurna dan salinan yang sama bunyinya. Maksud dari sama bunyinya tersebut adalah salinan akta sama persis isinya dengan minuta akta. ${ }^{7}$

Problem yang muncul terdapat pada kasus yang telah mendapatkan putusan dari Mahkamah Agung Republik Indonesia Nomor 1234/K/PID/2012 yang menjadikan Notaris

\footnotetext{
${ }^{5}$ Sudikno Mertokusumo, Hukum Acara Perdata Indonesia, Liberty, Yogyakarta, 1998, hlm 149.

${ }^{6}$ www.fairuzelsaid.wordpress.com/cyber-law-tanda-tangan-digital/ diakses Sabtu 17 Juni 2016.

7 Mulyoto, Perjanjian (Teknik,cara membuat, dan hukum perjanjian yang harus dikuasai), Cakrawala Media, Yogyakarta, 2011, hlm. 8.
} 
dan PPAT Ny. ENDANG MURNIATI, SH, Notaris di Kabupaten Sleman yang telah terbukti secara sah dan meyakinkan bersalah melakukan perbuatan pidana yaitu membuat minuta akta dengan memalsukan tandantangan penghadap, dimana penghadap mengalami kerugian secara materil akibat perbuatan terdakwa. Hal ini di perkuat dengan adanya bukti dokumen Berita Acara Pemeriksaan Laboratoris Kriminalistik Nomor Lab. 416/DTF/IV/2011 tanggal 3 Mei 2011 yang ditandatangani oleh Yayuk Murti Rahayu Bsc, Drs. Moh. Arief Buudiarto, dan Budi Santoso, S.Si. yang menyimpulkan bahwa tanda tangan Ir. Gregorius Daryanto atau penghadap adalah merupakan tanda tangan berbeda dalam akta surat kuasa jual nomor 51, surat kuasa jual Nomor 52 dan surat perikatan jual beli Nomor 65. Berdasarkan kejadian tersebut notaris Endang Murniati, S.H., dituntut oleh Jaksa Penuntut Umum dengan Pasal 263 ayat 1 dan Pasal 264 ayat 1 Kitab Undang-Undang Hukum Pidana (selanjutnya disebut KUHP) dengan tuduhan pembuatan surat/dokumen palsu.

\section{Rumusan Masalah}

Pertama, agaimanakah implikasi yuridis pemalsuan tanda tangan pada minuta akta terhadap Jabatan Notaris atas putusan Mahkamah Agung Nomor 1234 k/PID/2012? Kedua, bagaimanakah Akibat Hukum Terhadap Minuta Akta yang dipalsukan oleh notaris?

\section{Tujuan Penelitian}

Penelitian ini bertujuan untuk, pertama, mengetahui implikasi yuridis pemalsuan tanda tangan pada Minuta akta terhadap Jabatan Notaris atas putusan Mahkamah Agung Nomor 1234 k/PID/2012. Kedua, untuk mengetahui akibat hukum terhadap Minuta Akta yang dipalsukan oleh notaris.

\section{Metode Penelitian}

Jenis penelitian ini adalah penelitian normatif, sehingga dapat digunakan lebih dari satu pendekatan penelitian. ${ }^{8}$ Sedangkan Objek penelitian ini adalah "Implikasi Yuridis Pemalsuan Tanda Tangan Pada Minuta Akta Terhadap Jabatan Notaris.”(Studi Putusan Mahkamah Agung Nomor 1234 K/Pid/2012)”. Sedangkan pengumpulan bahan penellitian dilakukan dengan cara mempelajari data yang mempunyai hubungan dengan permasalahan,

\footnotetext{
8 Johnny Ibrahim, Teori dan Metodologi Penelitian Normatif, Bayumedia Publising, Malang, 2012, hlm. 300.
} 
yang diperoleh dari data sekunder yang didukung oleh data primer berupa wawancara dengan nara sumber, Data sekunder adalah data yang diperoleh dari bahan pustaka. ${ }^{9}$

\section{Hasil Penelitian dan Pembahasan}

\section{Implikasi Yuridis Pemalsuan Tandatangan Pada Minuta Akta Terhadap Jabatan Notaris atas putusan Mahkamah Agung Nomor 1234 K/PID/2012}

Kronologis dalam Putusan Mahkamah Agung Nomor 1234 K/PID/2012, Kasus yang terjadi di Yogyakarta, dimana kasus antara terdakwa yaitu Notaris Ny. Endang Murniati, SH dengan Saksi Korban yaitu Ir. Gregorius Daryanto, kasus tersebut telah mendapatkan kekuatan hukum tetap dari Mahkamah Agung Nomor 1234 K/ PID/2012.

Bahwa pada awal bulan Juni 2004 saksi korban Ir. Gregorius Daryanto telah dihubungi melalui telepon oleh saksi Hendricus Mulyono memberitahukan ada seseorang yang tertarik dan ingin membeli tanah milik saksi Ir. Gregorius Daryanto, Selanjutnya pada tanggal 5 Juni 2004 Dra. Mawar Muria Rini (Terdakwa dalam perkara terpisah) dengan ditemani oleh saksi Hendricus Mulyono dan saksi Edi Purwanto datang kerumah saksi Ir. Gregorius Daryanto dengan maksud untuk membicarakan kelanjutan jual beli tanah milik saksi Ir. Gregorius Daryanto, setelah terjadi tawar menawar akhirnya disepakati tanah tersebut dijual, kemudian Dra. Mawar Muria Rini bersedia membayar dengan uang tunai kepada saksi Ir. Gregorius Daryanto sedangkan sisa pembayaran akan dibayar dengan cara tukar guling tanah milik Dra. Mawar Muria Rini, untuk menindak lanjuti jual beli dengan cara tukar guling tanah antara saksi Ir. Gregorius Daryanto dengan Dra. Mawar Muria Rini tersebut, pada tanggal 10 Juni 2004 sekitar pukul 11.00 Wib. saksi Ir. Gregorius Daryanto bersama dengan saksi Hendricus Mulyono datang ke Kantor Terdakwa Notaris/PPAT ENDANG MURNIATI, SH yang beralamat di Jalan Colombo No. 2A Caturtunggal, Depok, Sleman, kemudian di Kantor Notaris/PPAT tersebut bertemu dengan Dra. Mawar Muria Rini dan Terdakwa ENDANG MURNIATI, SH selanjutnya oleh Terdakwa ENDANG MURNIATI, SH dijelaskan kepada saksi Ir. Gregorius Daryanto dan Dra. Mawar Muria Rini dengan disaksikan oleh Henricus Mulyono tentang rencana tukar guling tanah antara saksi Ir. Gregorius Daryanto dengan Dra. Mawar Muria Rini. Saksi Ir. Gregorius Daryanto langsung diminta oleh Terdakwa Endang Murniati, SH untuk menandatangani surat yang sudah dipersiapkan oleh Terdakwa Endang Murniati, SH, namun saksi Ir. Gregorius Daryanto pada saat itu tidak sempat membaca secara keseluruhan isi dari surat tersebut. Hal

9 Soejono Soekanto, Penghantar Penelitian Hukum, UI-Press, Jakarta, 2009, hlm. 51. 
tersebut dilakukan oleh saksi Ir. Gregorius Daryanto karena saksi percaya kepada Terdakwa Notaris/PPAT Endang Murniati, SH bahwa surat yang saksi tanda tangani tersebut adalah kesepakatan Tukar Guling, bukan akte jual beli tanah dan pada awal kedatangan saksi Ir. Gregorius daryanto yang ditemani saksi Hendricus Mulyono telah mendengar apa yang disampaikan dan ditanyakan oelh terdakwa Endang Murniati, SH tentang adanya rencana tukar guling tanah antara saksi Ir. Gregorius Daryanto dan Dra. Mawar Muria Rini.

Hakim dalam putusan Mahkamah Agung Nomor 1234 K/PID/2012 menyakini bersalah melakukan tindak pidana "PEMALSUAN SURAT BERUPA AKTA OTENTIK", seperti melakukan pemalsuakan tanda tangan penghadap. Berdasarkan kategori ini Notaris dikenakan 4 macam Implikasi yuridis terhadap Jabatan Notaris.

\section{Implikasi Perikatan Akta}

Menurut Penulis, keyakinan hakim tersebut memang sesuai dengan apa yang ada dalam pasal 48 ayat (1) Undang-Undang Nomor 2 Tahun 2012 tentang Jabatan Notaris, bahwa isi akta dilarang untuk dirubah dengan: 1. Diganti; 2. Ditambahi; 3. Dicoret; 4. Disisipkan; 5. Dihapus; dan/atau 6. Ditulis tindih.

Notaris dalam hal ini dapat dianggap turut melakukan dan melakukan kejahatan, karena terdapat bukti ketidak sesuaian antara tanda tangan dalam akta dan tanda tangan asli salah satu penghadap berdasarkan bukti hasil lab,akan tetapi dalam hal ini hakim tidak melihat penerbitan akta yang dibuat oleh Notaris Endang Murniati. SH..,seluruhnya berdasarkan pada keterangan penghadap, merupakan jenis akta para pihak (akta Partij), pertanggung jawaban pidana notaris yang timbul dari putusan tersebut tidak sesuai dengan Undang-Undang Nomor 30 Tahun 2004 tentang Jabatana Notaris dan Undang-Undang Nomor 2 Tahun 2014 perubahan Undang-Undang Nomor 30 Tahun 2004 tentang Jabatan Notaris.

Berdasarkan Pasal 1 angka 7 Undang-Undang Nomor 30 Tahun tentang Jabatan Notaris, Akta Notaris adalah akta otentik yang dibuat oleh atau dihadapan Notaris, menurut bentuk dan tata cara yang ditetapkan dalam undang-undang. Akta notaris dalam hal ini dapat dibagi menjadi dua macam / golongan akta notaris, yaitu:

1. Akta yang dibuat oleh notaris (akta relaas atau akta pejabat), yaitu akta yang dibuat oleh notaris memuat uraian dari notaris suatu tindakan yang dilakukan atas suatu keadaan yang dilihat atau disaksikan oleh notaris.

2. Akta yang dibuat dihadapan notaris (akta Partij), yaitu akta yang dibuat dihadapan notaris memuat uraian dari apa yang diterangkan atau diceritakan oleh para pihak yang menghadap kepada notaris. 
Berdasarkan hal diatas, akta notaris merupakan akta yang dibuat oleh notaris merupakan suatu alat pembuktian, dalam membuat suatu akta, seorang notaris harus memperhatikan norma-norma tersebut disamping kode etik dan ketentuan perundangundangan lainnya. maka penulis melihat Akta jual beli No.65 dan akta Menjual No.51 serta Akta menjual No. 52 dibuat berdasarkan seluruh keterangan dan pernyataan yang dijelaskan oleh para penghadap, sehingga akta tersebut merupakan akta yang dibuat berdasarkan kemauan para penghadap (Akta Partij), sehingga dalam pembuatan akta tersebut seorang notaris tidak memiliki kepentingan apapun terhadap isi dari kata yang dibuat. Notaris Endang Murniati, S.H.., membuat akta tersebut berdasarkan keterangan dan pernyataan yang diterima, sehingga semua isi dan materi dari akta tersebut adalah menjadi tanggung jawab dari pada penghadap, dalam Partij acte notaris tidak perlu membuktikan kebenaran materiil dari keterangan-keterangan para pihak.

Menurut Habib Adjie, ${ }^{10}$ pembuktian materil (materiele bewijskracht), merupakan kepastian tentang materi suatu akta, bahwa apa yang tersebut dalam akta merupakan pembuktian yang sah terhadap pihak-pihak yang membuat akta atau mereka yang mendapatkan hak dan berlaku untuk umum, kecuali ada pembuktian sebaliknya (tegenbewijs). Pernyataan yang dituangkan/dimuat dalam akta pejabat (atau berita acara), atau keterangan atau para pihak yang diberikan/disampaikan dihadapan Notaris (akta pihak) dan para pihak harus dinilai benar berkata yang kemudian dituangkan/dimuat dalam akta harus dinilai telah benar berkata, jika ternyata pernyataan/keterangan para penghadap tersebut mejadi tidak benar berkata, maka hal tersebut tanggung jawab para pihak sendiri. Notaris terlepas dari hal semacam itu. Dengan demikian isi akta notaris mempunyai kepastian sebagai yang sebenarnya, menjadi bukti yang sah untuk/diantara para pihak dan para ahli waris serta para penerima hak mereka.

Hakim haruslah melihat bahwa pada kenyataan Akta yang dibuat oleh Notaris Endang Murniati, S.H., hanya berdasarkan keterangan, pernyataan dan dibuat atas kehendak atau permintaan kliennya yaitu Ir. Gregorius Daryanto. Selaku notaris dalam hal ini hanya membuatnya dalam bentuk yang sudah ditentukan menurut undang-undang, dan juga notaris bukan pihak dalam akta tersebut, pencantuman nama notaris dalam akta karena perintah undang-undang.

${ }^{10}$ Habib Adjie, Menilai Pembuktian Akta Otentik, http;//habibadjie.dosen narotama.ac.id/files/2013/07 /Menilai-Pembuktin akta Notaris.pdf, dikases pada tanggal 11 Juni 2016 
Terhadap akta tersebut tidak terjadi hubungan hukum lagi, karena akta tersebut dapat dibatalkan dengan adanya pembuktian ketidak benaran terhadap akta serta kekuatan pembuktuan sebagai akta dibawah tangan tidak berlaku lagi dan telah ada keputusan pengadilan mahkamah agung yang sudah mempunyai kekuatan hukum tetap.

\section{Aspek Jabatan Adinistrasi Notarisnya}

Notaris dalam menjalankan tugasnya setelah ia membacakan akta hendaknya ia meminta tandatangan penghadap karena dengan tidak adanya tandatangan seorang penghadap di atas akta notaris dapat membahyakan notaris itu, kemungkinan selalu ada, bahwa seorang notaris menghadapi klien yang nakal atau (dalam hal suatu perdamaian) orang belum dapat mengatasi kejengkelan dan klien itu selalu dapat menyatakan tidak dapat menulis sedangkan kenyataannya ia bohong, notaris tersebut apabila benar si penghadap tidak dapat menadatangani akta maka dapat mengambil sidik jarinya dan notaris menyebutkan alasan bahwa penghadap tersebut tidak dapat menulis atau berhalangan membubuhi tanda tangannya. Sanksi administratif dapat berupa, peringatan tertulis, pemberhentian sementara, pemberhentian dengan hormat dan pemberhentian dengan tidak hormat.

\section{Aspek profesi terhadap keanggotaan}

Menurut penulis, implikasi hukum yang dapat ditimbulkan dari putusan Mahkamah Agung Nomor 1234 K/PID/2012 bila dilihat dari segi profesi terhadap keanggotaan adalah sebagai berikut :

1. Penjatuhan pidana/pemidanaan kepada Notaris akan berdampak pada berkurangnya kepercayaan masyarakat terhadap jabatan notaris, yang dapat menimbulkan ketidak pastian hukum yang mempengaruhi kinerja seorang notaris.

2. Sanksi yang ditunjukkan terhadap notaris juga merupakan sebagai penyadaran, bahwa notaris dalam melakukan tugas jabatannya tersebut telah melanggar ketentuan-ketentuan mengenai pelaksanaan tugas jabatan notaris sebagaimana tercantum dalam UUJN.

3. Penerapan sanksi pidana dalam putusan pengadilan yang telah memperoleh kekuatan hukum yang dalam amar putusan menghukum notaris untuk menjalani proses pidana tertentu sebagaimana amar putusan menunjukkan pertanggung jawaban pidana secara pidana terhadap notaris yang melakukan perbuatan melawan hukum seperti apa yang diatur dalam UUJN dapat di jatuhi sanksi pidana seperti apa yang diatur dalam kitab undang-undang hukum pidana (KUHP).

\section{Aspek Pidana}

Pada hakikatnya Sanksi merupakan instrumen yuridis yang di berikan apabila kewajiban-kewajiban atau larangan-larangan yang ada dalam ketentuan hukum dilanggar. ${ }^{11}$

11 Tatiek Sri Djamiati, dalam Habib Adjie, Op.Cit. hlm 90 
Ketidaktaatan atau pelanggaran terhadap suatu kewajiban tercantum dalam aturan hukum yang mengakibatkan terjadinya ketidakteraturan yang sebenarnya tidak diinginkan oleh aturan hukum yang bersangkutan.

Namun dapat saja Notaris melakukan suatu kesalahan dalam pembuatan akta, Kesalahan-kesalahan yang mungkin dapat terjadi, yaitu: 1. Kesalahan ketik pada salinan Notaris, dalam hal ini kesalahan tersebut dapat diperbaiki dengan membuat salinan baru yang sama dengan yang asli dan hanya salinan yang sama dengan yang asli baru mempunyai kekuatan sama seperti akta asli; 2. Kesalahan bentuk akta Notaris, dalam hal ini dimana seharusnya dibuat berita acara rapat tapi oleh Notaris dibuat sebagai pernyataan keputusan rapat; 3. Kesalahan isi akta Notaris, dalam hal ini mengenai keterangan dari para pihak yang menghadap Notaris, di mana saat pembuatan akta dianggap benar tapi ternyata kemudian tidak benar. ${ }^{12}$

Apabila ada akta Notaris dipermasalahkan oleh para pihak atau yang berkepentingan, maka untuk menyelesaikannya harus didasarkan pada kebatalan dan pembatalan akta Notaris sebagai suatu alat bukti yang sempurna. Kesalahan -kesalahan yang terjadi pada akta-akta yang dibuat oleh Notaris akan dikoreksi oleh hakim pada saat akta Notaris tersebut diajukan ke pengadilan sebagai alat bukti.

Pada umumnya akta itu adalah suatu surat yang ditanda tangani, memuat keterangan tentang kejadian-kejadian atau hal-hal yang merupakan dasar dari sesuatu perjanjian. Dapat dikatakan bahwa akta itu adalah suatu tulisan dengan mana dinyatakan sesuatu perbuatan hukum. Akta yang demikian ada yang sifatnya otentik dan ada yang sifatnya dibawah tangan.

Arti kata "menanda tangani" ( Ondertekenen) secara ethymologis (ilmu asal-usul kita) mudah ditemui, yaitu memberi tanda(teken) dibawah sesuatu, tetapi dalam praktek pemakaian kata-kata itu, definisi yang tertulis diatas tidak memuaskan dan pemakaian sehari-hari memberikan pengertian yang lebih khas, hal mana mungkin juga dimaksudkan oleh pembuat undang-undang tidak dapat di jelaskan dari kata "penananda tanganan".

Menurut Hermin Hediati Koeswadji suatu perbuatan melawan hukum dalam konteks pidana atau perbuatan yang dilarang oleh undang-undang dan diancam dengan pidana mempunyai unsur-unsur sebagai berikut: a. Unsur objektif adalah unsur-unsur yang terdapat di luar manusia yang dapat berupa: 1) Suatu tindakan atau tindak tanduk yang dilarang dan

12 Mudofr Hadi, Varia Peradilan Tahun VI Nomor 72, Pembatalan Isi Akta Notaris Dengan Putusan Hakim, 1991, hlm. 142-143. 
diancam dengan sanksi pidana, seperti memalsukan surat, sumpah palsu, pencurian; 2) Suatu akibat tenentu yang dilarang dan diancam sanksi pidana oleh undang-undang, seperti pembunuhan, penganiayaan; 3) Keadaan atau hal-hal yang khusus dilarang dan dIancam sanksi pidana oleh undang-undang, seperti menghasut, melanggar kesusilaan umum. b. Unsur subjektif yaitu unsur-unsur yang terdapat di dalam diri manusia.

Dengan demikian pemidanaan terhadap notaris dapat saja dilakukan dengan batasan jika: 1) Ada tindakan hukum dari notaris terhadap aspek formal akta yang sengaja, penuh kesadaran dan keinsyafan serta direncanakan, bahwa akta yang dibuat dihadapan notaris atau oleh notaris bersama-sama (sepakat) untuk dijadikan dasar untuk melakukan suatu tindakan pidana; 2) Ada tindakan hukum dari notaris dalam membuat akta dihadapan atau oleh notaris yang bila diukur berdasarkan Undang-Undang Jabatan Notaris tidak sesuai dengan UU Perubahan atas UUJN tersebut dan; 3) Tindakan notaris tersebut tidak sesuai menurut instansi yang berwenang untuk menilai suatu tindakan notaris, hal ini disebutkan dalam Majelis Pengawas Notaris. ${ }^{13}$

Terjadinya pemidanaan terhadap Notaris berdasarkan akta yang dibuat oleh atau di hadapan Notaris sebagai bagian dari pelaksanaan tugas jabatan atau kewenangan Notaris, tanpa memperhatikan aturan hukum yang berkaitan dengan tata cara pembuatan akta dan hanya berdasarkan ketentuan Kitab Undang-Undang Hukum Pidana (KUHP) saja, menunjukkan telah terjadinya kesalahpahaman atau penafsiran terhadap kedudukan Notaris sedangkan akta otentik yang dibuat oleh Notaris sebagai alat bukti dalam Hukum Perdata. Sanksi pidana merupakan ultimum remedium yaitu obat terakhir, apabila sanksi atau upayaupaya pada cabang hukum lainnya tidak mampu atau dianggap tidak mempan. ${ }^{14}$

Seorang notaris diharuskan selalu mengambil sikap cermat atau hati-hati dalam menyikapi setiap kasus dalam tugas jabatannya, mengingat seorang notaris telah memiliki kemampuan profesional baik secara teoritis maupun praktis.

Berdasarkan Wawancara dengan Notaris, Ety Ermawati selaku notaris di kota Yogyakarta, bahwa perubahan atas UUJN agar Notaris dapat terhindar dalam pelanggaran/perbuatan hukum, maka diperlukan bagi notaris untuk pintar-pintar membaca situasi dengan antisipasi dengan membuat surat pernyataan, bahwa yang menghadap benar adalah penghadap yang sebenarnya dan pada saat proses penanda tanganan hendaklah

${ }^{13}$ Habib Adjie, 2005, Batasan Pemidanaan Notaris, Jurnal Renvoi, Nomor 10-22 Tanggal 3 Maret, h1m. 123125.

14 Habib Adjie, 2005, “Batasan Pemidanaan Notaris”, Jurnal Renvoi, Nomor 10-22 Tanggal 3 Maret, hlm. 126. 
disaksikan oleh dua orang saksi. ${ }^{15}$ Dalam praktik ditemukan bahwa tindakan hukum yang dilakukan oleh notaris sebenarnya juga dapat dikualifikasikan sebagai suatu tindak pidana yang dilakukan notaris. Aspek yang dijadikan batasan dalam hal pelanggaran notaris harus diukur berdasarkan UU Perubahan atas UUJN, artinya apakah perbuatan yang dilakukan Notaris melanggar pasal-pasal tertentu dalam UU Perubahan atas UUJN bahwa akta yang bersangkutan telah sesuai dengan UU Perubahan atas UUJN, tetapi apabila menurut penyidik perbuatan tersebut merupakan suatu tindak pidana. Dengan demikin sebelum melakukan penyidikan lebih lanjut hendaknya meminta pendapat ahli yang mengetahui dengan pasti mengenai hal tersebut, yaitu dari organisasi jabatan Notaris. Ancaman sanksi yang demikian itu dimaksudkan agar dalam menjalankan tugas dan jabatannya, seorang Notaris dituntut untuk dapat bertanggung jawab terhadap diri, klien dan juga kepada Tuhan Yang Maha Esa.

\section{Akibat Hukum Terhadap Minuta Akta yang Dipalsukan Oleh Notaris.}

Salah satu syarat sah perjanjian yang terdapat dalam Pasal 1320 KUHPerdata yang berisi kesepakatan para pihak, kecakapan bertindak, adanya suatu hal tertentu yang diperjanjikan dan adanya suatu sebab yang halal terhadap perjanjian tersebut. Jika suatu akta menimbulkan suatu pidana maka persyaratan perjanjian dilihat unsur-unsur perjanjian yang terkandung didalamnya. Para ahli hukum seperti Sudikno Mertokusuno, Mariam Darus, dan J J.Satrio bersepakat bahwa unsur-unsur perjanjian itu terdiri dari unsur esensialia, unsur naturalia, dan unsur aksidentalia. ${ }^{16}$

Unsur pertama lazim disebut dengan bagian inti perjanjian, unsur kedua dan ketiga disebut bagian non inti perjanjian. Unsur esensialia adalah unsur yang mutlak harus ada untuk terjadinya perjanjian, agar penjanjian itu sah dan ini merupakan syarat sahnya perjanjian. Jadi keempat syarat dalam Pasal 1320 KUHPerdata merupakan unsur esensialia perjanjian. Dengan kata lain, sifat esensialia perjanjian adalah sifat yang menentukan perjanjian itu tercipta (constructieve oordeel).

Unsur naturalia adalah unsur yang lazim melekat pada perjanjian, yaitu unsur yang tanpa diperjanjikan secara khusus dalam perjanjian secara diam-diam dengan sendirinya dianggap ada dalam perjanjian. Unsur ini merupakan sifat bawaan (natuur) atau melekat

\footnotetext{
${ }^{15}$ Hasil Wawancara pada saat Pra Magang di Kantor Notaris Ety Ermawati selaku Notaris di kota Yogyakarta, pada tanggal 10 Mei 2016.

${ }^{16}$ Kartini Muljadi dan Gunawan Widjaja, Perikatan yang Labir dari Perjanjian, Jakarta: Raja Grafindo Persada,2010), hlm. 84.
} 
pada perjanjian. Misalnya penjual harus menjamin cacat-cacat tersembunyi kepada pembeli. Sedangkan unsur aksidentalia, artinya unsur yang harus dimuat atau dinyatakan secara tegas di dalam perjanjian oleh para pihak. Misalnya jika terjadi perselisihan, para pihak telah menentukan tempat yang dipilih. Untuk membuktikan suatu akta tersebut sah atau tidak sah dalam penelitian ini, digunakan asas praduga sah. Asas praduga sah (VermoedenVanRechtmatigheid) atau Presumptio Iustae Causa adalah asas yang menganggap sah suatu produk hukum sebelum adanya putusan pengadilan yang mempunyai kekuatan hukum tetap yang menyatakan tidak sah. Dengan adanya asas ini maka akta otentik yang dibuat oleh Notaris harus dianggap sah dan mengikat para pihak sebelurn dapat dibuktikan ketidakabsahan dari aspek lahiriah, formal dan materiil akta otentik tersebut.

Dalam ketentuan yang tersebut dalam Pasal 41 UUJN-P yang menyatakan jika Notaris rnelanggar ketentuan sebagaimana dimaksud dalam Pasal 38, Pasal 39, dan Pasal 40 UUJN-P mengakibatkan akta hanya mempunyai kekuatan pembuktian sebagai akta di bawah tangan, maka akta Notaris hanya mempunyai kekuatan pembuktian sebagai akta dibawah tangan, namun apabila para pihak dapat membuktikan ketidakbenaran akta otentik tesebut dalam persidangan di pengadilan dan mengakibatkan akta tersebut dapat dibatalkan serta kekuatan pembuktian sebagai akta di bawah tangan tidak akan berlaku Iagi. Karena asas praduga sah ini berkaitan dengan akta yang dapat dibatalkan, merupakan suatu tindakan mengandung cacat yaitu tidak berwenangnya Notaris untuk membuat akta secara lahiriah, formal, materiil dan tidak sesuai dengan aturan hukum tentang pembuatan akta Notaris.

Akibat hukum terhadap akta otentik yang dibuat oleh Notaris secara melawan hukum sehingga menyebabkan akta otentik menjadi akta dibawah tangan serta akta tersebut dapat dibatalkan telah sejalan dengan teori kewenangan dan konsep perlindungan hukum. Seperti dikemukakan dalam teori kewenangan, Notaris dalam membuat akta otentik termasuk dalam kewenangan secara atribusi, berdasarkan ketentuan Pasal 15 ayat (1) UU Perubahan atas UUJN. Terjadinya suatu akibat hukum yaitu berupa akta otentik menjadi akta dibawah tangan dan akta tersebut dibatalkan diakibatkan oleh penyalahgunaan wewenang yang dilakukan oleh Notaris, dimana Notaris dalam menjalankan wewenangnya telah melanggar ketentuan perundangundangan yang mengakibatkan kerugian bagi para pihak dan mengakibatkan berubahnya kekuatan pembuktian akta dan adanya pembatalan akta otentik tersebut oleh pengadilan.

\section{Penutup}

Pertama, implikasi terhadap jabatan notaris dapat dikategorikan dalam empat (4) aspek yakni, pertama implikasi perikatan akta, Kedua Aspek terhadap jabatan Administrasi; 
Ketiga, Aspek Profesi terhadap Keanggotaan; Keempat, aspek pidana;. Kedua, akibat Hukum Terhadap Minuta akta yang dipalsukan oleh Notaris yaitu mengakibatkan akta hanya mempunyai kekuatan pembuktian sebagai akta di bawah tangan, apabila para pihak dapat membuktikan ketidakbenaran akta otentik tesebut dalam persidangan di pengadilan dan mengakibatkan akta tersebut dapat dibatalkan serta kekuatan pembuktian sebagai akta di bawah tangan tidak akan berlaku Iagi. Karena asas praduga sah ini berkaitan dengan akta yang dapat dibatalkan, merupakan suatu tindakan mengandung cacat yaitu tidak berwenangnya Notaris untuk membuat akta secara lahiriah, formal, materiil dan tidak sesuai dengan aturan hukum tentang pembuatan akta Notaris.

\section{Daftar Pustaka}

\section{Buku}

Adjie, Habib, Sanksi Perdata dan Administratif Terhadap Notaris Sebagai Pejabat Publik, Bandung, Refina Aditama, 2008

Adjie I,Habib, Hukum Notaris Indonesia (Tafsir Tematik Terhadap UU No.30 Tahun 2004 Tentang Jabatan Notaris),Bandung ;PT. Refika Aditama, 2008.

Adam, Muhammad, Asal Usul Dan Sejarah Notaris, Bandung, Sinar Baru, 1985

Amiruddin dan H. Zainal Asikin, Pengantar Metode Penelitian Hukum, Cetakan Keenam,Jakarta; PT Rajagrafindo Persada, 2012.

Andarsasmita, Komar, Notaris I, Bandung : Sumur, 1984

Anshori, Addul Ghofur, Lembaga Kenotariatan Indonesia,Perspektif Hukum dan Etika, Yogyakarta: UII Press, 2009.

Apeldoorn, L.J. van, Pengantar Ilmu hukum, Jakarta: Pradnya Paramita, 2001.

Asikin, Zainal, 2012, Pengantar Metode Penelitian Hukum, Cetakan Keenam, Jakarta; PT Rajagrafindo Persada, 1996.

Asri Wijayanti dan Prof. Lilik Sofyan Achmad, Strategi Penulisan Hukum, Bandung,Lubuk Agung, 2011.

Budiono,Herlien, Kumpulan Tulisan Hukum Perdata di Bidang Kenotariatan, Buku Kedua, Cetakan Pertama,Bandung; PT. Citra Aditya Bakti, 2010).

D. Schafmeister, N.Kijzer, E.PH.Sitorus, Editor J.E.Sahetapy, Hukum Pidana, Yogyakarta: Liberty, 1995.

F. Sumaryono, Etika Profesi Hukum, Norma-Norma Bagi Penegak Hukum, Yogyakarta : Kanisius, 1995.

Hadjon, Philipus M., et.al., Hukum administrasi dan Good Governance, (Universitas Trisakti: Jakarta, 2010).

HAMEL, Van, Inleiding tot de studie van het Nederlandse Strafrecht, dalam Lamintang, Dasar-Dasar Hukum Pidana Indonesia, Bandung, Sinar baru, 1985. 
H.R, Ridwan, Hukum Administrasi Negara Edisi Revisi,Jakarta; RajaGrafindo Persada, 2010.

Ibrahim, Johnny, Teori dan Metodologi Penelitian Normatif, Malang: Bayumedia Publising, 2012.

J.J.J M. Wuisman, Penelitian Ilmu-ilmu Sosial, Jilid I,Jakarta; UI Press, 1996.

Kansil,C.S,T., Pokok-Pokok Etika Profesi Hukum,Jakarta; Pradnya Paramitha, 1979.

Kanter,E.Y. Etika Profesi Hukum; Sebuah Pendekatan Religius,Jakarta: Storia Grafika, 2001).

Kie,Tan Thong, Serba-Serbi Praktek Notariat,Bandung; Alumni,1987.

Kohar, A. Notaris Dalam Praktek Hukum, Bandung: Alumni, 1985

K. Prent, C.M, J. Adi Subrata dan W.J.S Poerwadarminta, Kamus Latin Indonesia,Jakarta: Kanisius, 1969.

Lamintang, Dasar-Dasar Hukum Pidana Indonesia, Bandung: Sinar Baru, 1985.

, delik-delik Khusus, Mandar Maju; Bandung , 1991

Marzuki,Peter Mahmud,Penelitian Hukum,cet.Kedua Jakarta: Kencana Prenad, Media Grup,2006.

Mertokusumo, Sudikno, Hukum Acara Perdata Indonesia, Yogyakarta: Liberty, 1998. , Mengenal Hukum Suatu Pengantar, Yogyakarta: Liberty, 2003.

Moeljatno, Asas-Asas Hukum Pidana, Jakarta : Bina Aksara, 1987

Muhammad, Abdul Kadir, Hukum dan Penelitian Hukum, Bandung; PT Citra Aditya Bakti, 2004

Mulyoto, Perjanjian (Teknik,cara membuat, dan hukum perjanjian yang harus dikuasai), (Yogyakarta: Cakrawala Media, 2011)

Notodisoerjo, Soegondo, Hukum Notariat di Indonesia, Jakarta: RajaGrafindo Persada, 1993.

Prajitno,A.A. Andi, Apa dan Siapa Notaris di Indonesia?, Cetakan Pertama, Surabaya; Putra Media Nusantara, 2010.

Priyatno, Dwidja,Kebijakan Legislasi tentang Sistem Pertanggungjawaban Pidana Korporasi di Indonesia, Bandung; CV. Utomo, 2004.

Salim HS, Teknik Pembuatan Akta Satu,Jakarta; Raja Grafindo, 2015.

Simons, leerboek Van Het Nederlandse Strafrecht I. P.Noordhoff N.V Groningen, Jakarta: Batavia, 1937.

Soekanto, Soerjono dan Sri Mamudji,Penelitian Hukum Normatif suatu Tinjauan Singkat,ed.1 cet 10,Jakarta; Raja Grafindo Persada, 2007. , Penelitian Hukum, Kencana Prenada Media Grup, Jakarta, 2006 , Sosiologi Suatu Pengantar,Jakarta; Raja Grafindo Persada, 2001. , Penghantar Penelitian Hukum, Jakarta; UI-Press, 2009 
Soegondo, Notodisoerjo, Hukum Notariat di Indonesia, Jakarta: RajaGrafindo Persada,1993.

Soemoatmodjo, Soertardjo, Apakah Notaris Pejabat Pembuat akta Tanah Pejabat lelang, Yogyakarta: Liberty, 1986

Soerodjo, Irmawan, Kepastian Hukum Hak Atas Tanah di Indonesia,Surabaya; Arkola, 2003.

Subrata, K. Prent, c.m, j.Adi dan W.J.S Poerwadarminta, Kamus Latin Indonesia, Yogyakarta: Kanisius, 1969.

Tedjosaputro, Liliana, Etika Profesi dan Profesi Hukum, Semarang, Aneka Ilmu, 2003.

Tobing, Lumban, Peraturan Jabatan Notaris, Jakarta; Erlangga, 1980.

Theo, Huijbers, Filsafat Hukum dalam Lintasan Sejarah, Yogyakarta; Kanisius,1995.

Untung, Budi, 22 Karakter Pejabat umum (Notaris atau PPAT), Yogyakarta; Andi, 2015)

Wijayanti, Asri, dan Lilik Sofyan Achmad, Strategi Penulisan Hukum, Bandung: Lubuk Agung, 2011.

Widjaja, Kartini, Muljadi dan Gunawan Perikatan yang Lahir dari Perjanjian, (Jakarta: Raja Grafindo Persada,2010), hlm. 84.

WJS. Poerwadinata, Kamus Umum Bahasa Indonesia,Jakarta; Balai Pustaka, 1986.

\section{Karya Ilmiah}

Dungge, Rasjuddin (tanpa tahun), Kepastian Hukum, diakses dari: http: //rasjuddin.blogspot.com/, pada hari Jumat, tanggal 21 Maret 2016, pukul 17.05 WIB.

Habib Adjie, 2005, Batasan Pemidanaan Notaris, Jurnal Renvoi, Nomor 10-22 Tanggal 3 Maret.

Habib Adjie, Menilai Pembuktian Akta Otentik, http;//habibadjie.dosen narotama.ac.id/files/2013/07 /Menilai-Pembuktin akta Notaris.pdf, dikases pada taggal 11 November 2016

Tim Penyusun Pedoman Penyusunan Tugas Akhir Fakultas Hukum Universitas Islam Indonesia, Pedoman Penyusunan tugas Akhir (Skripsi,legal,memorandum dan Studi Kasus hukum), Fakultas Hukum Universitas Islam Indonesia, Yogyakarta, 2011

Tim Peneliti Kamus-Pusat Pembinaan dan Pengembangan Bahasa, Kamus Besar Bahasa Indonesia, Jakarta: Balai Pustaka, 1989

I Dewa Gede Atmadja, Penafsiran Konstitusi Dalam Rangka Sosialisasi Hukum: Sisi Pelaksanaan UUD 1945 Secara Murni dan Konsekwen, Pidato Pengenalan Guru Besar dalam Bidang Ilmu Hukum Tata Negara Pada Fakultas Hukum Universitas Udayana 10 April 1996

Utomo,Budi Mahasiswa Magister Kenotariatan Fakultas Hukum UNS, Analisis Putusan Hakim Terhadap Tindak Pidana Pemalsuan Akta Otentik Yang Dilakukan Oleh Notaris 
Setiawan, 1995, Hak Ingkar dari Notaris dan Hubungannya dengan KUHP (suatu kajian uraian yang disajikan dalam Kongres INI di Jakarta.

Saputra,Asbudi Dwi Fakultas Hukum Program Pascasarjana (S2) Universitas Hasanuddin, Pertanggungjawaban Pidana Notaris/PPAT Selaku Pejabat Umum Dalam Pemalsuan Dokumen Akta Tanah.

Tedja,Mario A. 2012, diakses dari: http://mariotedja.blogspot.com/2012 /12/teorikepastian-dalam-prespektifhukum.html, pada hari Jumat, tanggal 21 Maret 2016, pukul 17.00 WIB.

\section{Peraturan Perundang-undangan}

Kitab Undang-undang Hukum Perdata.

Kitab Undang-undang Hukum Pidana.

Putusan Mahkamah Agung Nomor 1234/K/PID/2012.

Undang-undang Nomor 2 Tahun 2014 tentang Perubahan Atas Undang-undang Nomor 30 Tahun 2004 tentang Undang-undang Jabatan Notaris. 